\title{
Variants of Conjoined Twins - Two Case Reports
}

\author{
Nahreen Akhtar ${ }^{1}$, Sabina Karim ${ }^{2}$, Tabassum Parveen ${ }^{3}$, Syeda Sayeeda $^{3}$, Firoza Begum ${ }^{4}$ \\ ${ }^{1}$ Associate Professor Fetomaternal Medicine Wing, Department of Obs \& Gynae, BSMMU, ${ }^{2}$ Registrar, Pediatric Oncology, National \\ Institute of Cancer \& Research Hospital, ${ }^{3}$ Assistant Professor, ${ }^{4}$ Professor, Fetomaternal Medicine Wing, Department of Obs \& Gynae, \\ BSMMU, Dhaka
}

\begin{abstract}
:
Conjoined twins are identical twins whose bodies are joined in utero. Parasitic twins occur when a twin embryo begins developing in utero, but the pair does not fully separate, and one embryo maintains dominant development at the expense of the other which becomes vestigial. Vestigial twin appears as parasitic because it is incompletely formed or wholly dependent on the body function of the complete fetus. The independent twin is called the autosite. In conjoined twins both remain healthy. In this study we have presented one parasitic twin and another conjoined twin. In $1^{\text {st }}$ case a 28 yrs old lady delivered a female parasitic twin by caesarean section due to failure of induction of labour. Unfortunately the baby died on $3^{\text {rd }}$ postoperative day. In $2^{\text {nd }}$ case, a $25 y$ ears old lady diagnosed as a case of conjoined twin by ultrasonography for the first time at her $35 \mathrm{wks}$ of pregnancy. Emergency caesarean section was arranged on the day of admission as she started labour pain. A conjoined twin was delivered which were joined at thorax and abdomen and both were alive. Parents were offered surgical separation but they refused it and take the babies home.
\end{abstract}

Key words: Conjoined twin, parasitic twin, omphalopagus.

[BSMMU J 2012; 5(1):65-68]

\section{Introduction:}

Conjoined twins are a rare and complex complication of monozygotic twinning, which is associated with high perinatal mortality. One of the commonest defects of blastogenesis is monozygotic twinning resulting in separate or conjoint twins. The latter includes category of internal, "endoparasitic," or fetus-in-fetu twins. ${ }^{1}$ Conjoined twinning only arises when the twinning event occurs at about the primitive streak stage of development, at about 13-14days after fertilization, and is exclusively associated with monoamniotic monochorionic type. Conjoined twins (also known as Siamese twins) are identical twins whose bodies are joined in utero. It is a rare phenomenon, the occurrence is estimated to range from 1 in 50,000 to 1 in 100,000 births, with a somewhat higher incidence in Southwest Asia and Africa. ${ }^{2}$ Approximately half are stillborn, and a smaller fraction of pairs born alive having abnormalities which is incompatible with life. The overall survival rate for conjoined twins is approximately $25 \%$. The condition is more frequently found among females, with a ratio of $3: 1{ }^{2}$

Two contradicting theories exist to explain the origins of conjoined twins. The older and most generally accepted theory is fission, in which the fertilized egg splits partially. The second theory is fusion, in which a fertilized egg completely separates, but stem cells (which search for

Address for Correspondence: Dr. Nahreen Akhtar, Fetomaternal Medicine Wing, Department of Obstetric \& Gynaecology, BSMMU, Dhaka similar cells) find like-stem cells on the other twin and fuse the twins together. Conjoined twins share a single common chorion, placenta, and amniotic sac, although these characteristics are not exclusive to conjoined twins as there are some monozygotic but non-conjoined twins that also share these structures in utero. ${ }^{4}$ Surgery to separate conjoined twins may range from relatively simple to extremely complex, depending on the point of attachment and the internal parts that are shared. Most cases of separation are extremely risky and life-threatening. In many cases, the surgery results in the death of one or both of the twins, particularly if they are joined at the head and brain. This makes the ethics of surgical separation, where the twins can survive if not separated, contentious. Dreger found the quality of life of twins who remain conjoined to be higher than is commonly supposed. ${ }^{5}$ There are nearly a dozen different types of conjoined twins. One of the most common type is thoracopagus twins. These twins are connected at the upper portion of the torso. When thoracopagus twins share a heart, depending on how closely they are joined, makes it nearly impossible to separate them and save them both. Thoracopagus twins occurs about 40 percent of all conjoined cases. ${ }^{2}$ Another common type of conjunction is called omphalopagus, where twins are connected from the breastbone to the waist. About 33 percent of all conjoined cases are categorized as omphalopagus. ${ }^{2}$ These twins may share a liver, gastrointestinal or genitourinary functions, but rarely share a heart. One of the rarest types of conjoined twins is 
craniophagus twins, which are joined at the cranium or head. In fact, only 2 percent of all conjoined twins are joined in this way. Parasitic twins are those that are asymmetrically conjoined, resulting in one twin that is small, less formed and dependent on the larger twin for survival. It occurs in $10 \%$ of cases. The surgical separation of conjoined twins is a delicate and risky procedure, requiring extreme precision and care. Therefore, the decision to separate twins is a serious one. Mortality rates for twins who undergo separation vary, depending on their type of connection, and the organs they share. For example, twins joined at the sacrum, at the base of the spine have a 68 percent chance of successful separation, whereas, in cases of twins with conjoined hearts at the ventricular (pumping chamber) level, there are no known survivors. Although success rates have improved over the years, surgical separation is still rare. It is only after twins are born that doctors can use magnetic resonance imaging, ultrasound and angiography to find out what organs the twins share. In order to determine the feasibility of separation, doctors must carefully assess how the twins' shared organs function. After separation, most twins need intensive care facility because of the malformation and extensive operation they require. ${ }^{6}$

\section{Case Report-1}

A 28-year-old women hailing from Munshiganj, Dhaka got herself admitted on $12^{\text {th }}$ May, 2010 at her 30 weeks of pregnancy with multiple congenital abnormality. She was on irregular antenatal check up. At her 30 weeks of pregnancy anomaly scan was done for two times. Scan report shows soft tissue mass in sacral region with gastroschisis. She had no history of intake of any drugs or fever during her pregnancy period. Decision for termination was taken after proper counseling. Pregnancy was induced by prostaglandin gel (prostaglandin $\mathrm{E}_{1}$ ) 8 hourly for 3 days with no response. So pregnancy was terminated by cesarean section. A female baby with conjoined twin (one parasitic twin) with gastroschisis weighing $1 \mathrm{~kg}$ was delivered (Fig.-1). The parasitic twin has one long lower limb and one short limb attached at the sacral portion of the autosite. The baby was shifted to neonatal ICU. The postoperative period of the patient was uneventful. The baby died on $3^{\text {rd }}$ postoperative period. Patient was discharged on $5^{\text {th }}$ postoperative day (POD).

\section{Case Report -2}

A 25-year-old woman, house wife of middle class family hailing from Narsingdi got herself admitted into BSMMU hospital on $1^{\text {st }}$ March, 2011 at her 38weeks of pregnancy with conjoined twin pregnancy with rupture of membrane. This was not a booked case. At her 35 weeks pregnancy she visited her Obstetrician for the $1^{\text {st }}$ time. Ultrasonography was done and it shows 29weeks 3 days twin pregnancy with breech presentation with small for gestational age. A repeat USG was done and showed thoracoabdominal conjoined twin pregnancy with intrauterine growth restriction (IUGR). She had no family history of twin pregnancy. She had one female child, delivered by caesarean section and age of the child is 5 yrs. On $1^{\text {st }}$ March, 2011 she noticed sudden gush of pervaginal watery discharge and got herself admitted in BSMMU. On the same day USG was repeated and shows conjoined twin of 31-32 wks pregnancy with breech presentation and severe oligohydramnios. On perabdominal examination height of uterus was 36wks pregnancy size which is more than gestational age. Caesarean section was done on the day of admission. A thoracoabdominal conjoined female twin weighing 1320 gm were delivered per abdominally by breech extraction. (Fig.-2). Both the babies were alive. Apgar score was poor and baby was sent to NICU of this hospital. The babies needed bag and mask ventilation. Both the babies had cleft lip and cleft palate with single umbilical cord. The babies parents refuses any further treatment or surgery.

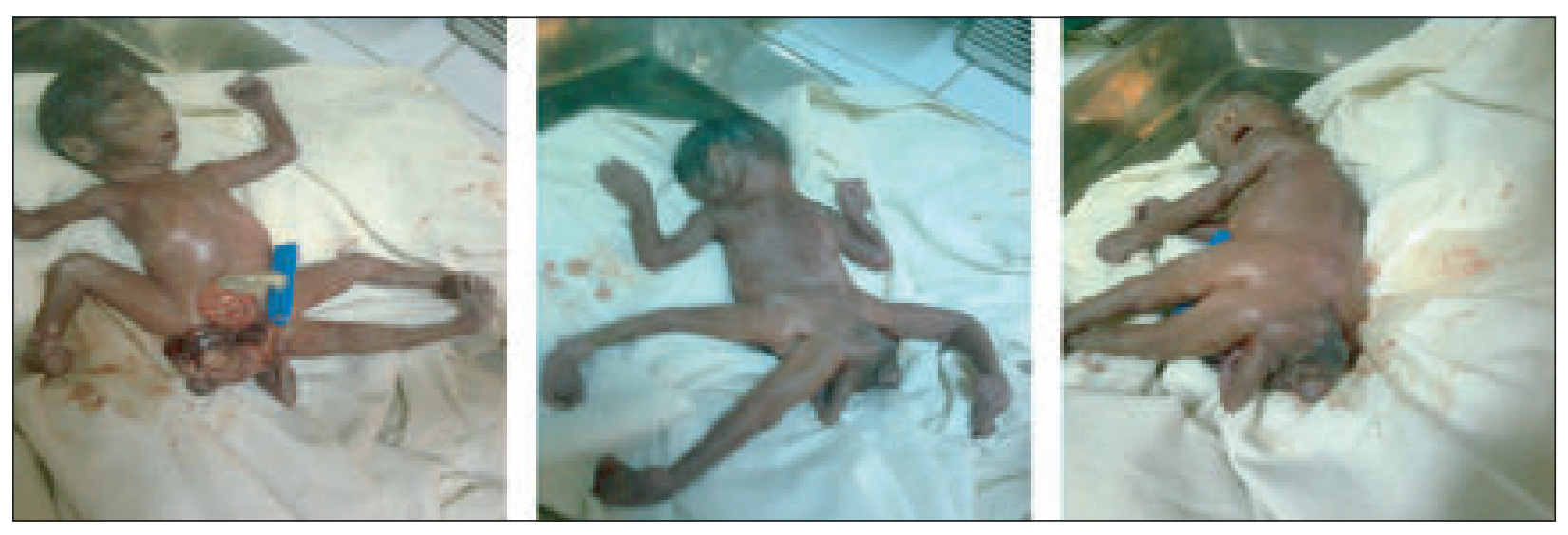

Fig.-1: Parasitic conjoined twin (Case-1) 


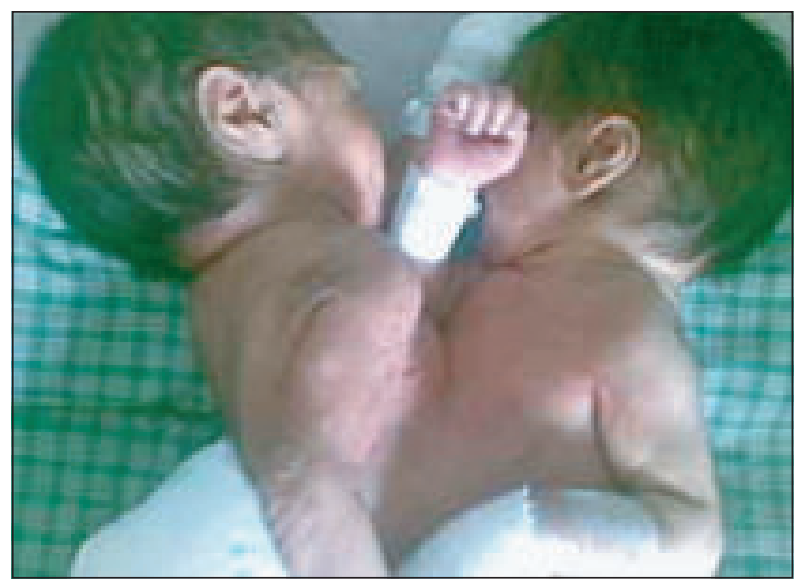

Fig.-1: Thoraco-abdominal conjoined twin (case - 2)

\section{Discussion:}

Conjoined twinning is a relatively rare events in any community, with a rate 1.58 per 100,000 maternities reported in the EUROCAT database. The incidence of conjoined twinning in the Maltese islands has been shown significantly higher (2.5times) than that reported by the remaining EUROCAT contributes. The rate reported 3.98 per 100,000 maternities. ${ }^{7}$ Parasitic twins are conjoined twin that are asymmetrically conjoined, resulting in one twin that is small, less formed, and dependent on the larger twin for survival. It occurs in 10\% among all conjoined twins. In one study they showed a variant conjoined twins in which one twin was incomplete. The infant was fully developed in all external aspects except for a parasitic body conjoined with her sacrococcygeal region. ${ }^{7}$ In the $1^{\text {st }}$ case, reported here one was fully developed, though the baby had gastroschisis and another parasitic one attached in the sacrococcygeal region. The attached parasitic one had one long limb and one short limb with a portion of anal region were attached with the fully developed one. A rare example of rachipagus conjoint parasitic twinning in a newborn girl was described. A lipomatous mass with an attached hind limb (with fused feet) and a rudimentary vertebral arch were found adherent to the dorsal vertebral arches of the auto site in the thoracolumbar region. There was a clear cleavage plane between the autosite and the parasite. Microscopic sections of the excised specimen showed only gut. The autosite had no other congenital anomalies except for spina bifida in the thoracolumbar region with unfolding of the underlying cord. In the absence of underlying lifethreatening anomalies, surgical excision of the parasitic twin and treatment of the associated anomalies of the autosite is known to offer gratifying result. ${ }^{8}$
In one study more than 1260 individual cases were collected from the literature and reported abnormal anatomy was tabulated. They found that association of conjoined twins and their parasitic with fetus in fetu, acardiacs and teratomas was more frequent than could be attributed to chance. Several reports of chromosomal abnormality suggests that perhaps, at least on occasion, it is genetically imperfect embryo that develops into a defective fetus. ${ }^{9}$ Early prenatal diagnosis of conjoined twins allows better counseling of the parents regarding the management options, including continuation of pregnancies with postnatal surgery, termination of pregnancy or selective feticide in case of a triplet pregnancy. ${ }^{10}$ In case-2, bodies were fused from the lower thorax to upper belly (omphalopagus). We could not confirm about the fusion of internal organs because the babies parents did not want to do any investigations. In one study they reported a case of female omphalopagus conjoined twins. There was no cross circulation into the livers and the gastrointestinal tract was not conjoined. They were successfully separated. ${ }^{11}$

Statistics shows that only a few hundred conjoined twins are born across the globe each year, which is about one in every 100,000 births. In Bangladesh few cases were notified. Survival of conjoined twins is very rare in Bangladesh. A total of three such twins were admitted to Dhaka Medical College Hospital in the last three and a half years, but none of them survived. ${ }^{12}$ Four previous operations in Bangladesh to separate conjoined twins in the past few years have resulted in the deaths of all but two children. A four-month-old Bangladeshi girl died hours after marathon surgery by 50 doctors, nurses and technicians to separate her from her twin sister in August $2009 .{ }^{13}$

One conjoined twins, Hasan and Hossain, at Islami Bank Hospital in 2003 were successfully separated. They were joined together at the liver and the sternum. The survival of Hasan and Hossain is a good news story in a country where natural disasters, poverty and corruption often dominate the headlines. It reflects the enormous developments that have been made in medical care in Bangladesh. ${ }^{14}$ One of the reported case was Kiron, a two headed twin born in Kasehebpur ,100 miles from capital, Dhaka delivered by cesarean section weighing $5.5 \mathrm{~kg}$. He had one stomach and was eating normally with his two mouth. They unable to determine whether the baby had one or two sets of vital organs. Unfortunately, this baby did not survive once the parents took him home as they could not afford his medical care. ${ }^{15}$ 
On 22 ${ }^{\text {nd }}$ August, 2007 Trishna Pal, wife of Joyprokash $\mathrm{Pal}$, of Palpara village in Birganj upazila of Dinajpur, gave birth to the conjoined twins by caesarean section at a local clinic. The babies were brought to the capital for treatment on 31st January,2008 and admitted to the hospital. Around six-month, old two sisters were conjoined at the lower part of their chests and abdomens. Doctors at Dhaka Shishu Hospital separated conjoined twins Moni and Mukta. The operation was performed successfully in Bangladesh. The separation of the twins was carried out by a 10 -member team of surgeons and anesthetists. ${ }^{12}$

Banya ("Flood") and Barsha ("Rain"), born in northern Bangladesh, were joined at the stomach and chest but have separate heads and limbs. Their mother, a nurse, brought the twins to Dhaka, where they were monitored for three weeks before doctors decided to operate. In August 2008, they were successfully separated fourmonth-old conjoined twins by surgeons from Bangabandhu Shiekh Mujib Medical University (BSMMU) Hospital. The operation lasted for seven hours. More than 50 doctors, nurses and technicians were involved in the operation. Though Barsha died within a very short time after the operation, Banya survived well. ${ }^{16}$

In another case, Krishna and Trishna had craniopagus (joined at the back of skull). They were successfully separated at 2yrs of age in the Royal Children's Hospital, Melbourne which was one of longest operations ever under taken in Australia and following 18 months preparation. Both girls survived after separation; continue to undergo physical rehabilitation in Australia. ${ }^{17}$ Another case, where newborn twins joined at the stomach and legs in Chittagong, Bangladesh. After efforts by a team of surgeons to separate them failed and the babies died within few minutes after surgery. The twins - one male and the other's sex not identified were born with four hands, three legs and no developed excretory organs. The cause of death was given as multiple organ failure. ${ }^{13}$

\section{Conclusion:}

Conjoined twin is rare event of monozygotic twin. If it is diagnosed earlier especially those conjoined twin which are not compatible with life, or those parents who can't bear the costs of surgery can be terminated earlier to have a vaginal delivery.

\section{References:}

1. Gilbert BE, Opitz JM, Debich SD, Muller T, Arnold SR, et al. Fetus in fetu form of monozygotic twinning with retroperitoneal teratoma. Am J Med Genet 2003; 120(3) : 406-12.

2. Conjoined Twins - Wikipedia, the free encyclopedia. My Web Search [internet] cited 2011; 16 April; Available from : http:/ / en. Wikipedia. Org/ wiki/ Conjoined twins.

3. James LS and James TG. The craniopagus malformation: classification and implications for surgical separation. Brain 2006; 129(5):1084-1095.

4. Le T, Bhushan V, Vasan N. First Aid for the USMLE Step 1: 2010 20th Anniversary Edition. USA: The McGraw-Hill Companies, Inc. pp. 121.

5. Alice D. One of Us: Conjoined Twins and the Future of Normal, Harvard, 2004; 9 Available from http:///www. Amazon. Com/ gp/product/ 0674018257.

6. Conjoined Twin Facts. My web search[internet]. Cited 2010 Jan 8; Available from: www. Umm.edu/ conjoined- twins/ facts. $\mathrm{Htm}$ - Cached - similar University of Maryland Medical Center 1-800-492-5538.

7. Savona VC, Grima S, Butligieg GG. Conjoined twinning in the Maltese Island. J Obstet Gynaecol 2009; 29(7): 549 - 604.

8. Ratan SK, Rattan KN, Magu S, Rohilla S, Purwar P, et al. Thoracolumber rachipagus parasite. Pediatr Surg Int 2004; 20(4): 298-300.

9. Spenser R.Parasitic Conjoined Twins:external, internal (fetuses in fetus and teratoma ), and detached acardiacs. Clin Anat 2001; 4 (6) : 428-44.

10. Pajkrit E, Jaunianx E. First trimester diagnosis of conjoined twins. Prenat Diagn 2005;25(9): 820-6.

11. Chaumoitre K, Merrot T, Petit P, Pascal T, Portier F, et al. Fetal pre and postnatal diagnosis of omphaloxiphophagus conjoined twins. J Radiol 2001; 82(3pt 1): 268-701

12. Atastain L. Conjoined twin separated in Dhaka. [cited 2003 June 26]; Available from: news.bbc.co.uk/2/hi/south_asia/ 3024162.stm.

13. Bangladeshi conjoined twins. AFP [cited 2009 July 7]; Available from: dienews.asiaone.com/News/Latest $\% 2 \mathrm{BNews} /$ Asia/Story/ A1Story...

14. Conjoined twin separated. DSH [cited 2003 June 26]; Available from: www.thedailystar.net/newDesign/news-details. php?nid=125553.

15. Kiron. A two headed person born in Bangladesh. Xenophilia 2008. [cited 2008 Aug 27]; Available at word press. com./ two headed baby - born - in Bangladesh.

16. Bangladesh surgeons separate conjoined twins. AFP. 2011. [cited 2008 Aug 6]; Available from: google.com/article/ ALeqM5gL6fxakEtuavNW24Y_WLuh7NMNow

17. Martin J. nz herald co nj.2009. [cited 2009 Nov 13]; Available from: http:// www.nz herald. co. nz/ Bangladesh/ news/ article. cfm? -id 